\title{
Phytochemical investigation and potential pharmacologically active compounds of Rumex nepalensis: an appraisal
}

\author{
Yilma Hunde Gonfa ${ }^{1,2}$, Fekade Beshahn ${ }^{2,3}$, Mesfin Getachew Tadesse ${ }^{2}$, Archana Bachheti ${ }^{4}$ and \\ Rakesh Kumar Bachheti ${ }^{2^{*}}$ (iD
}

\begin{abstract}
Background: Rumex nepalensis, a widely known traditional medicinal plant and is used as the source of medicines and human diet in various communities. Currently, the phytochemical investigation and pharmacological studies of $R$. nepalensis are of significant research interest. Therefore, the current review is mainly focused on the phytochemical investigation and pharmacological applications of $R$. nepalensis

Main body: Various secondary metabolites like emodin, endocrocin, chrysophanol, neopodin, physcion, torachrysone, aloesin, catechin, quercetin, resveratrol, and their derivatives were isolated from root and aerial parts of the plant. Both isolated compounds and extracts from $R$. nepalensis are reported to have pharmacological activities such as antiinflammatory, antioxidant, antimicrobial, wound healing, and anti-plasmodial activities

Conclusions: Different parts of $R$. nepalensis have ethnomedicinal importance. $R$. nepalensis is one of the potential sources of pharmacologically active extracts and isolated compounds. In future $R$. nepalensis can play a vital role for the preparation of modern drugs.
\end{abstract}

Keywords: Medicinal plants, Rumex nepalensis, Pharmacological activities, Phytochemical

\section{Background}

Starting from human civilization, plants, animals, and minerals are being used by people for their rich nutritional and medicinal sources. Especially, plants have been exploited since the ancient history for their remedial purposes [1]. Several research reports showed about 270,000 plant species have been discovered, while biodiversity gives approximately around 500,000 species on earth [2]. It was reported that about 50,000 plant species were used as traditional medicines in different forms [3]. There is no synthetic substitute available for about 121 major plant-based drug molecules, which are comprising 45 from tropical and 76 from subtropical areas [4]. Several plants continue to be important sources of

\footnotetext{
* Correspondence: rkbachheti@gmail.com

${ }^{2}$ Department of Industrial Chemistry, College of Applied Science, Addis Ababa Science and Technology University, P.O.Box: 16417, Addis Ababa Ethiopia

Full list of author information is available at the end of the article
}

many chemical compounds used in pharmacological activities and attracted the attention of scientific communities. Research activities on natural products have confirmed that there are strong efforts for the isolation, identification, and structure elucidation of secondary metabolites from plants and their uses as active components in medicinal and drug preparations $[5,6]$ and good source of nutraceutical products. The World Health Organization (WHO) report showed more than $80 \%$ of the population on the globe is practicing traditional medicines for primary health care due to the biological effects of present organic compounds [7].

In the world, there is traditional medicine knowledge or practices that are related to human beings and livestock's health. The natural product extraction method is the oldest human practice, and usage of plant extracts and isolated products as a diet supplement, medicine, cosmetics, and agricultural applications counts back many centuries $[8,9]$. Wild plants are also reported as 
potential phytoremediation of toxic elements like heavy metals and monitoring excess metallic nutrients in agricultural soils and water [10-13]. Nowadays, the industrial applications of plant-based organic products have obtained attention due to the broad-range of their chemical compositions with minimum side effects [6]. Natural product extracts contain quite different chemical constituents that have distinct pharmacological and biological properties. These secondary metabolites comprise carbon-based compounds such as sugars, fatty acids, terpenoids, sterols, flavonoids, tannic acids, saponins, anthraquinones, vitamin $\mathrm{C}$, steroids, and phenolic acids, and nitrogen-based compounds such as alkaloids, amino acids, and protein-based compounds [14]. Some valuable medicines obtained from plant-based drugs like taxol, podophyllotoxin, digitoxigenin, gitogenin, digoxigenin, vinblastine, vincristine, tubocurarine, morphine, codeine, aspirin, atropine, pilocarpine, capsaicin, allicin, curcumin, artemisinin, and ephedrine are good representative examples of pharmaceutical drugs [15]. The research interest towards phytochemical activities has been steadily growing in developing and developed countries because of the rising credit of non-narcotic plant products, lesser side effects, and affordability at low cost. Even, sometimes medicinal plants are the only way of health care accessible to the community that has no access to modern medical services [16].

The recent phytochemical and pharmacological studies revealed isolation and characterization of many novel biologically active compounds for the synthesis of drug candidates serving to manufacture advanced therapeutic drugs [17-20]. Modern drugs that are produced from natural products have a huge potential that still exists in plants for the production of many more novel organic compounds. Scientists throughout the world have identified thousands of phytochemicals that have inhibitory effects against all types of microorganisms [21]. Similarly, they were reported as potential sources of phytochemical compounds that are applied for the wide biological activities. Rumex species, the second largest family of polygonaceae, have been identified as a promising source of bioactive and pharmacologically active compounds [22]. Almost all Rumex species are known for their ethnomedicinal values in the world [23]. Although the genus contains about 250 plant species, phytochemical and pharmacological studies have been conducted on only about 50 species as some reports on this plant species have shown the use of leaves, aerial, and roots of the plant either as treatment of several health disorders, food, coloring agent, or phytoremediation [12, 24]. Various phytochemicals and many secondary metabolites have been reported from different parts of this plant. Recently, there are significant and renewed interests in these phytochemical compounds as potential drugs or as sources for novel drugs [5, 25]. For various medication purposes, Rumex plants have been processed for a long period of time in different preparation forms like decoction, crushing, chewing, making juice/paste, crude extracts, fixed oils, and essential oils [26].

Most Rumex species are reported to treat constipation, wound, bleeding, inflammation, ulcer, tumor, mild diabetes, diarrhea, edema, jaundice, and hypertension and have diuretic and analgesic effects [26, 27]. They are also identified to relieve diseases like oxidative stress and liver, skin, nervous, cognitive, and gallbladder disorders [28-30]. Rumex nepalensis spreng. has wide-spectrum therapeutic activities and was extensively used as traditional medicine for centuries [4]. A vast literature survey revealed that diverse secondary metabolites like anthraquinones, flavonoids, naphthalenes, terpenes, stilbenoids, tannins, phenols, and saponins had been reported from solvent extracts of root parts of the $R$. nepalensis [31]. Solvent extracts or isolated compounds from the plant species are reported for their constipation, bleeding, tinea, pain, and purgative activities [32-34]. Leaves and immature roots of $R$. nepalensis are also reported to be used as a food supplement and dyeing agent $[35,36]$. But, if it is consumed in greater quantity, oxalic acid present in the plant needs big attention to avoid the risk factor of calcium oxalate (kidney stone) formation [24]. Similarly, the bark and leaf of the plant were reported for their cleansing purposes in bathing and washing clothes in Ethiopia [37]. R. nepalensis is further reported for its powerful phytoremediation effects due to its potential accumulation of metals from soils and water for monitoring the level of macro and traces of metal elements in the diet supplements $[12,38]$. The plant's flower part has been found to be a good medicine to cure joint pains [39]. Looking over the current publication status, thus far no comprehensive review paper has been published on $R$. nepalensis. This review paper describes botanical description, ethnomedicinal uses, phytochemistry, and pharmacological applications of $R$. nepalensis

\section{Main text}

\subsection{Methods}

In this review, some important data on the availability, botanical description, and pharmacological activities of $R$. nepalensis was collected from PubMed, Google scholar, Royal Society of Chemistry, Scifinder, Scopus, and "Science Direct" databases. This review article aims to make a focused appraisal on the current research trends on $R$. nepalensis regarding its ethnobotanical features, ethnomedicinal uses, phytochemical investigation, and pharmacological properties.

\subsection{Botanical description of $R$. nepalensis 2.2.1 Morphological features of $R$. nepalensis}

Rumex genera are usually plants with erect and long taproots. $R$. nepalensis is a $50-$ to $100-\mathrm{cm}$-tall plant, 
glabrous, branched, grooved, and greenish in color [40]. It is a perennial herb with large roots that grow deep into the soil and erect stems. The leaves are edible, 5 - to 10-cm long, arrow- or wide-shaped at its base, with wide- and long-stalked lower, either oblong or ovate, and have a petiole. Its basal leaves have 4- to $10-\mathrm{cm}-$ long petiole [41]. The plant flowers are reddish, bisexual, and spirals, forming long and nearly leafless racemes [42] (Fig. 1).

\subsubsection{Taxonomy of the R. nepalensis}

$R$. nepalensis is one of the 250 plant species in the Rumex genera. Flowering and fruiting times are in between April and September based on the altitudinal situation of the regions where it grows [40, 43]. Its meiotic chromosome ploidy count is reported as $n=50(10 \times)$ [43]. It is a perennial, ascending herb and, in various communities, are commonly known by different vernacular names. In different communities, it is locally known by different names as a few of them are listed below in Table 1.

\subsubsection{Geographical distribution of R. nepalensis}

Rumex genera are commonly distributed in the northern part of the globe especially in Africa, America, Asia, and Europe countries, but the introduction of the plant species is possible almost everywhere. $R$. nepalensis is tolerant to wide ecological locations. It is commonly a weed plant that grows at higher altitudes between 900 and $4000 \mathrm{~m}$ in various weather conditions [41]. Different reports in literatures have shown that the plant grows widely in Africa, India, Turkey, China, Myanmar, Indonesia, Afghanistan, Japan, Pakistan, Tajikistan, Vietnam, and Bhutan [40, 47].

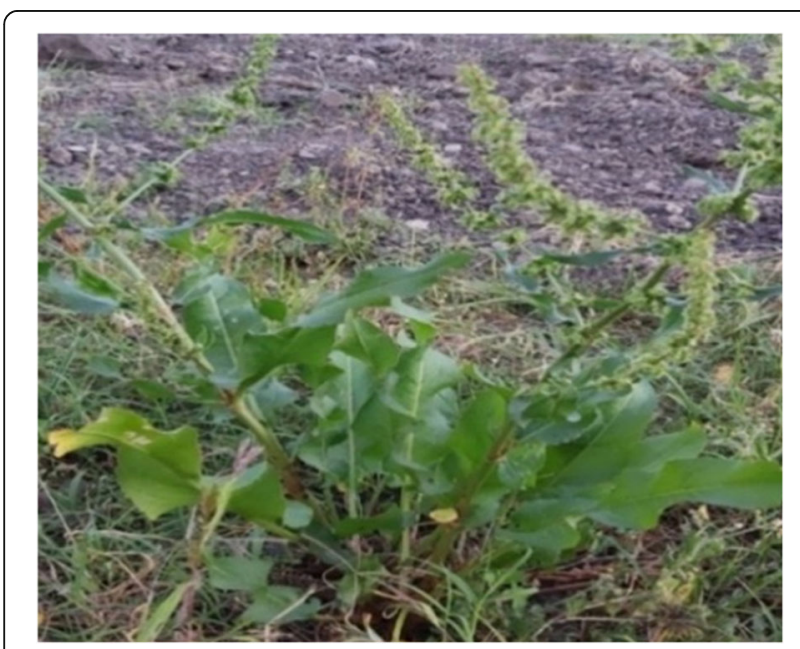

Fig. 1 Photograph of $R$. nepalensis

\subsubsection{Ethnomedicinal values of R. nepalensis}

Rumex species have a number of ethnomedicinal uses; for instance, $R$. acetosa, $R$. acetosella, $R$. abyssinicus, $R$. crispus, $R$. nepalensis, $R$. sanguineus, $R$. tuberosus, $R$. thyrsiflorus, and $R$. vesicarius are some good examples [24]. It has been reported that $R$. acetosa, $R$. acetosella, $R$. nervosus, and $R$. nepalensis leaves are also used as part of human diet $[31,48]$. In some regions, $R$. nepalensis leaves are employed as food supplement mainly in the form of vegetable soups. $R$. nepalensis is a very important weed plant in the field of traditional medicines. Several experimental reports have confirmed that $R$. nepalensis has numerous medicinal benefits. The plant roots, leaves, and flower parts are often used for the remedial purposes of various health disorders through different modes of preparations. It was also reported that some communities cook leaves and young shoots of $R$. nepalensis as a vegetable diet which gives a lemon taste to dishes [18]. Further, the plant has shown the coloring nature in food [40]. Ethnomedicinal study on herbal plants has specified active importance of $R$. nepalensis to increase its capacity in drug industries [49]. Various solvent extracts of the plant parts have been reported showing promising biological activities [16, 50]. For instance, roots of $R$. nepalensis are reported to be traditionally used to treat pain, inflammation, bleeding, tinea, tumor, and constipation [51] and have diuretic, analgesic, anticancer, antimicrobial, and antioxidant activities. The leaves part of the plant are also used commonly to treat colic and headaches [52]. For example, investigation of methanolic (95\%) extract of the leaves part in rat model was tested nontoxic until $4000 \mathrm{mg} / \mathrm{Kg}$ dose (i.e., $\mathrm{LD}_{50}>4000 \mathrm{mg} / \mathrm{Kg}$ ) [53]. To the best of our knowledge, only a few reports are documented in the literature for the use of flower parts of $R$. nepalensis. The summary of ethnomedicine uses and the mode of preparation of this medicinal plant against human and livestock diseases are summarized in Table 2.

\subsection{Phytochemistry of $R$. nepalensis}

\subsubsection{Potential bioactive compounds from R. nepalensis}

Phytochemical investigation of $R$. nepalensis has shown a large number of organic complex and biologically active compounds. Most previous research activities that were undertaken regarding phytochemical studies have exhibited diversified secondary metabolites like flavonoids, phenols, anthraquinones, naphthalenes, saponins, cardiac glycosides, stilbeniods, terpenes, sterols, tannins, steroids, and reducing sugars [51, 67, 68]. Currently, most of the literatures related to the solvent-based isolation and characterization of $R$. nepalensis have been from the root parts of the plant species for the evidence not given clearly. For the plant species, phytochemical screening indicated the presence of alkaloid compounds 
Table 1 Vernacular names of R. nepalensis

\begin{tabular}{lll}
\hline Local names (language) & $\begin{array}{l}\text { Place/ } \\
\text { country }\end{array}$ & References \\
\hline $\begin{array}{l}\text { Sheep sorrel, Nepal dock, Himalayan dock } \\
\text { (English) }\end{array}$ & Not stated & {$[40,41]$} \\
Amlya, Amlora, Jangli palak, Malori (Hindi) & India & {$[18]$} \\
Aliphiri (Kashmir) & India & {$[40]$} \\
Pahari palang (Bengali) & India & {$[44]$} \\
Shalkhay (Paksitani) & Pakistan & {$[33,45]$} \\
Kathura (Uttarakhandi) & India & {$[40]$} \\
Sukkankeri (Tamil) & India & {$[4]$} \\
Shulti (Afaan Oromo); Lut (Amharic) & Ethiopia & {$[37,46,47]$} \\
\hline
\end{tabular}

[42, 69] even though they are not confirmed by phytochemistry reports.

2.3.2 Phytochemical compounds isolated from $R$. nepalensis Phytochemical screening activities of $R$. nepalensis have shown the plant species contain a broad spectrum of secondary metabolites. However, only a few of them have been reported by scientific communities. Studies on the solvent extracts of roots of $R$. nepalensis have confirmed $[51,67]$ that it contains phytochemical compounds like anthraquinones (Fig. 2), naphthalenes (Fig. 3), flavonoids (Fig. 4), terpenoids, and sterols (Fig. 5).
Table 3 shows the various terpenoid and phenolic compounds obtained from the root extracts of $R$. nepalensis. It is clear in Table 3 that mainly oxygenated compounds were identified from $R$. nepalensis plant root extracts using different solvent systems such as ethanol, methanol, n-butanol, or their mixtures. For instance, n-butanol extract of the root part of the plant has been reported to give different classes of organic compounds like endocrocin (6), nepalenside A (7), nepalenside B (8), rumexoside (9), torachrysone (10), orientaloside (11), aloesin (15), catechin (17), resveratrol (21), orcinol glucoside (22), and (3,5Dimethoxy-4-hydroxyphenol)-1-O- $\beta$-D-(6-O-galloyl) glucose (23). Of course, compounds (7) and (8) were reported for the first time from this plant species. It was stated that physcion (2), rumexoside A (12), and rumexoside B (13) were obtained from the ethanol extract of the root part of the plant by partitioning with pet ether, ethyl acetate, and water, and compounds (12) and (13) were newly reported from this plant. Isolated organic compounds like chrysophanol (1), emodin (3), chrysophanol-8-O- $\beta$-D-glucopyranoside (4), emodin-8-O- $\beta$-D-glucopyranoside (5), 3-Omethyl epicatechin (16), quercetin-3-O- $\beta$-D-glucoronate (18), and $\beta$-sitosterol-3-O- $\beta$-D-glucoside (20) have been also reported from the methanol/water $(80 / 20)$ extract of the root part of the plant using cold percolation for $24 \mathrm{~h}$.

The same report again claimed that compounds (16), (18), and (20) had been isolated for the first time from the plant species. Aloesin (15), rumexoside (9), orientaloside

Table 2 Ethnomedicinal importance of $R$. nepalensis and its mode of preparation for treatment of different ailments

\begin{tabular}{|c|c|c|c|c|}
\hline $\begin{array}{l}\text { Part } \\
\text { used }\end{array}$ & Ethnomedicinal importance & $\begin{array}{l}\text { Place/ } \\
\text { country }\end{array}$ & Mode of preparation & References \\
\hline \multirow[t]{6}{*}{ Root } & $\begin{array}{l}\text { Used as purgative, antitumor, anti-inflammatory, and treatment for dislo- } \\
\text { cated bones }\end{array}$ & Nepal & Decoction & [52] \\
\hline & Treat wounds, pimples, and ringworm & India & Crushing root and making paste & [54] \\
\hline & Used to cure skin disorders and eczema & India & Crushing root and making paste & [55] \\
\hline & $\begin{array}{l}\text { Treat stomach ache, tooth ache, tonsillitis, ascariasis, rabies, and body } \\
\text { swelling }\end{array}$ & Ethiopia & Chewing the root & {$[56,57]$} \\
\hline & Relieve stomach disorders & Ethiopia & Chewing the root & [58] \\
\hline & Used as purgative & Pakistan & Chewing the root & [33] \\
\hline \multirow[t]{8}{*}{ Leaf } & Treat headaches, abdominal colic, skin diseases, wound, and allergies & $\begin{array}{l}\text { Nepal/ } \\
\text { India }\end{array}$ & $\begin{array}{l}\text { Decoction and making juice of the } \\
\text { leaf powder }\end{array}$ & {$[52,59]$} \\
\hline & $\begin{array}{l}\text { Treat ulcers, kwashiorkor, worms, HIV/AIDS, opportunistic diseases, and } \\
\text { show HIV-1 activity indices }\end{array}$ & Rwanda & $80 \%$ Ethanolic leaf extract & {$[60,61]$} \\
\hline & Used as ethnoveterinary to treat stomachache & Ethiopia & Crushing & [58] \\
\hline & Used as antiseptic against wounds and skin disorders & Pakistan & Decoction & {$[62,63]$} \\
\hline & Relieve irritation of sting nettle, stomachache, and snakebite & India & Crushing and making juice & {$[64,65]$} \\
\hline & Treat hypertension, amoebic dysentery, and hemorrhoids & Ethiopia & Decoction & [66] \\
\hline & Treat swelling and joint pain & India & Crushing & [43] \\
\hline & Used to treat cuts & Pakistan & Decoction & [63] \\
\hline Flora & Cure joint pain and body ache & India & $\begin{array}{l}\text { Powder/paste application to the } \\
\text { infected body }\end{array}$ & [39] \\
\hline
\end{tabular}


<smiles></smiles>

(1) $\mathrm{R}_{1}=\mathrm{CH}_{3} ; \mathrm{R}_{2}=\mathrm{R}_{3}=\mathrm{H}$ (Chrysophanol),

(2) $\mathrm{R}_{1}=\mathrm{CH}_{3} ; \mathrm{R}_{2}=\mathrm{OCH}_{3} ; \mathrm{R}_{3}=\mathrm{H}$ (Physcion)

(3) $\mathrm{R}_{1}=\mathrm{CH}_{3} ; \mathrm{R}_{2}=\mathrm{OH} ; \mathrm{R}_{3}=\mathrm{H}$ (Emodin)

(4) $\mathrm{R}_{1}=\mathrm{CH}_{3} ; \mathrm{R}_{2}=\mathrm{H} ; \mathrm{R}_{3}=\boldsymbol{\beta}$-D-Gluco pyranosyl

(Chrysophanol-8-O- $\beta$-D-Gluco pyranoside)

(5) $\mathrm{R}_{1}=\mathrm{CH}_{3} ; \mathrm{R}_{2}=\mathrm{OH} ; \mathrm{R}_{3}=\boldsymbol{\beta}$-D-Gluco pyranosyl(Emodin-8-O- $\beta$-D-Gluco pyranoside)<smiles></smiles>

(6) Endocrocin

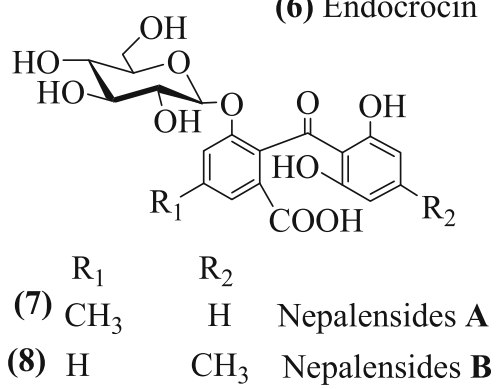

Fig. 2 Isolated anthraquinone compounds from the root extracts of $R$. nepalensis

(11), and torachysone (10) have shown an antiinflammatory activity. Similarly, chrysophanol (1), emodin (3), and some of their derivatives (4) and (8) which were reported from Soxhlet methanol root extracts have anticancer, antifungal, antioxidant, and anti-inflammatory activities. Neopodin (14) and chrysophanol (1) which were obtained from methanol extract of the root part of the $R$. nepalensis have shown anti-inflammatory activity. Neopodin (14) was also identified for ethyl acetate extract of the root of the plant and reported to show strong antiinflammatory activities. According to some other reports, in the methanol extract of the root part of $R$. nepalensis, secondary metabolites like torachrysone (10), epicatechin gallate (19), orcinol glucoside (22), and aloesin (15) were identified for their antimicrobial, antidiabetic, antiinflammatory, antioxidant, and antitumor activities. Nepalenside A (7) and nepalenside B (8), the two newly isolated compounds from ethanol fractions of the root part of the plant species, were also reported for their antidiabetic and cytotoxic properties. Alcoholic solvent root extractions on
R. nepalensis showed the isolation of oxygenated secondary metabolites which have wide phytotherapeutical activities (Table 3).

\subsection{Pharmacological activities of $R$. nepalensis}

Rumex species have shown potent pharmacological activities. Root and aerial parts of Rumex species are used as medicines throughout the world for a variety of human diseases such as purgative, tinea, antioxidant, cytotoxic, antipyretic, antidiarrhea, antiviral, antibacterial, antifungal, and anti-inflammatory activities [15, 29]. Leaves, roots, and few flora parts of $R$. nepalensis have been reported mostly to be used to treat skin disorders and syphilitic ulcers also. Similarly, there are many studies on this medicinal plant showing its properties as purgative, analgesic, antipyretic, antifungal, anti-inflammatory, antibacterial, and skeletal muscle relaxant activities [53, 71]. In this regard, $R$. nepalensis has been reported as potential pharmacologically active plant against various ailments. Some of these activities are discussed as follow.

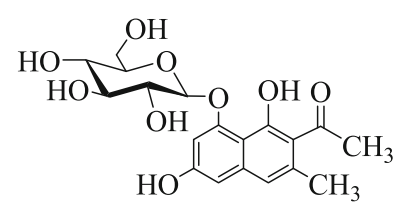

(9) Rumexoside

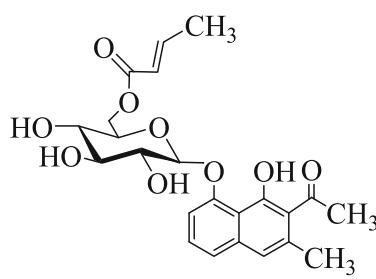

(12) Rumexneposide A

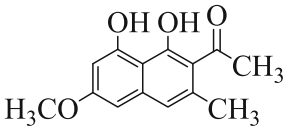

(10) Torachrysone
(13) Rumexneposide B

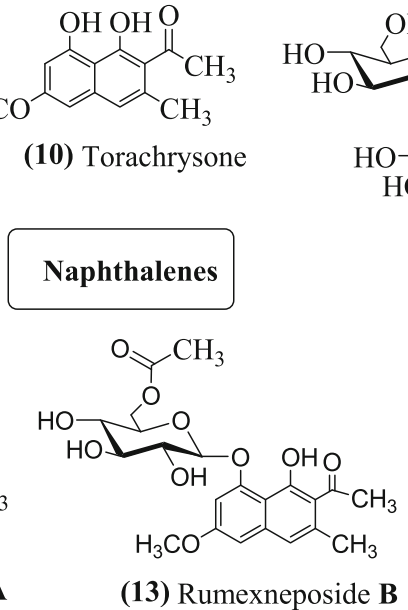

Fig. $\mathbf{3}$ Isolated naphthalene compounds from the root extracts of $R$. nepalensis 


<smiles>COC1Cc2c(O)cc(O)cc2OC1c1ccc(O)c(O)c1</smiles>

(16) 3-O-methyl epicatechin<smiles>Oc1cc(O)c2c(c1)OC(c1ccc(O)c(O)c1)C(O)C2</smiles>

(17) Catechin

(15) Aloesin

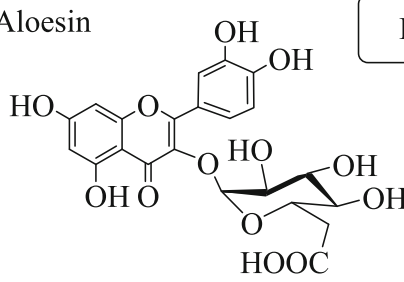

(18) Quercetin-3-O-ßB-D-glucoronate
Flavonoids

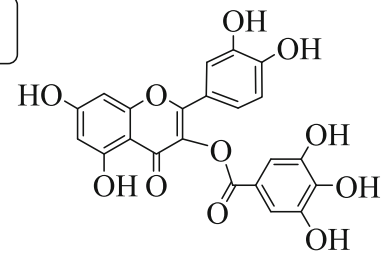

(19) Epicatechin-3-O-gallate

Fig. 4 Isolated flavonoids from the root extracts of $R$. nepalensis

\subsubsection{Anti-inflammatory activity}

Different studies have indicated that solvent extracts and isolated pure compounds of $R$. nepalensis are rich in antiinflammatory activities. There were reports on the investigation of chloroform and ethyl acetate extracts of the root of the plant which have shown significant antiinflammatory activity $[46,52]$. For the treatment of acute inflammation of the mouse model, extracts of ethyl acetate and chloroform revealed a reduction in ear edema [40]. Another report for ethanolic extract of the root part of $R$. nepalensis demonstrated an anti-inflammatory effect that has a strong comparison with the standard diclofenac [4]. Some isolated compounds like neopodin, chrysophanol, and their derivatives from ethyl acetate fractions of the root part of the plant species have shown an improved anti-inflammatory activity than the control ibuprofen [70]. Similarly, ethyl acetate extract of the root part of $R$. nepalensis was reported to show moderate to strong inhibitory effects against inflammatory effects on COX-1 comparing with indomethacin and COX-2 compared with celecoxib as positive controls. The presence of anthraquinones and naphthalenes in the root extract of the plant species is responsible for the inhibition effects observed [23]. From the root part of the plant, secondary metabolites such as chrysophanol, physcion, endocrocin, chrysophanol-8-O- $\beta$ D-glucopyranoside, nepodin, and nepodin-8-O- $\beta$-D-glucopyranoside were specifically reported for their antiinflammatory activities [68].

\subsubsection{Antioxidant activity}

The phytochemical screening of solvent extracts of roots and leaves of $R$. nepalensis has exhibited that the plant contains potential bioactive compounds with significant antioxidant activities [24, 53]. For instance, polyphenols and flavonoids isolated from the plant species have<smiles>CCCC(C)C(C)CCC1(C)CCC2C(CC3(C)C2C=C2CC(O)CCC23C)C1(C)CCC(C)C(C)C</smiles>

(20) B-sitosterol-3-O-ß--D-glucoside
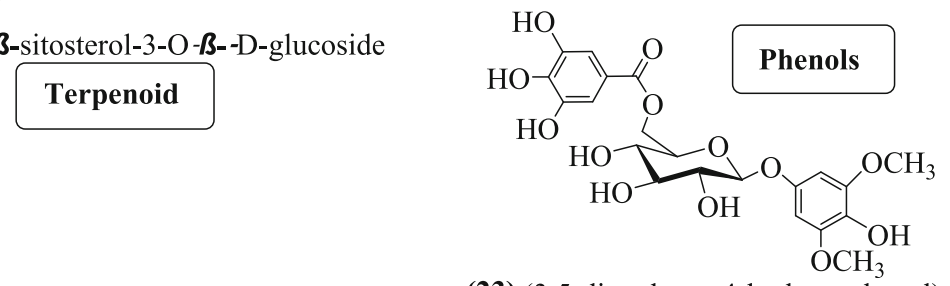

(23) (3,5-dimethoxy-4-hydroxyphenol)-1-O-ß-D-(6O-galloyl) glucose

Fig. 5 Isolated terpenoid and phenol compounds from the root extracts of $R$. nepalensis 
Table 3 Major compounds isolated from root extracts of $R$. nepalensis and their pharmacological activities

\begin{tabular}{|c|c|c|c|}
\hline Isolated compounds & Method used & Pharmacological activities & References \\
\hline $\begin{array}{l}\text { Rumexoside (9) Torachysone (10) } \\
\text { Orientaloside (11) } \\
\text { Aloesin (15) }\end{array}$ & $\begin{array}{l}\text { Solvent extraction } \\
\text { (n-butanol) }\end{array}$ & Anti-inflammatory & {$[4,24,40]$} \\
\hline $\begin{array}{l}\text { Chrysophanol (1) and its derivatives (4) } \\
\text { Emodin (3) and its derivatives (8) }\end{array}$ & $\begin{array}{l}\text { Soxhlet extraction } \\
\text { (methanol) }\end{array}$ & $\begin{array}{l}\text { Antifungal } \\
\text { Antioxidant } \\
\text { Anticancer } \\
\text { Anti-inflammatory }\end{array}$ & {$[46,51,67]$} \\
\hline Neopodin (14) & $\begin{array}{l}\text { Solvent extraction } \\
\text { (ethyl acetate) }\end{array}$ & Anti-inflammatory & {$[40]$} \\
\hline $\begin{array}{l}\text { Nepalenside A (7) } \\
\text { Nepalenside B (8) }\end{array}$ & $\begin{array}{l}\text { Solvent extraction } \\
\text { (ethanol) }\end{array}$ & $\begin{array}{l}\text { Antidiabetic } \\
\text { Cytotoxic }\end{array}$ & {$[40,51]$} \\
\hline $\begin{array}{l}\text { Torachrysone (10) } \\
\text { Aloesin (15) } \\
\text { Epicatechin gallate (19) } \\
\text { Orcinol glucoside (22) }\end{array}$ & $\begin{array}{l}\text { Solvent extraction } \\
\text { (methanol) }\end{array}$ & $\begin{array}{l}\text { Antimicrobial } \\
\text { Antioxidant } \\
\text { Antitumor } \\
\text { Antidiabetics } \\
\text { Anti-inflammatory }\end{array}$ & {$[4,24,67]$} \\
\hline $\begin{array}{l}\text { Chrysophanol (1) } \\
\text { Neopodin (14) }\end{array}$ & $\begin{array}{l}\text { Solvent extraction } \\
\text { (methanol) }\end{array}$ & Anti-inflammatory & [70] \\
\hline
\end{tabular}

revealed important health benefits. These phytochemicals are reported as antioxidant compounds because of their single oxygen quenchers and reducing properties [72]. The leaves part of the plant are rich sources of natural antioxidants [4]. When comparing the ethanolic root extract of $R$. nepalensis with the free radical scavenging nature of the standard ascorbic acid, the extract has shown better scavenging activity [46, 73]. Antioxidant activity of extract of the root part of $R$. nepalensis by solvents such as chloroform, ethyl acetate, acetone, ethanol, methanol, and water have been also investigated and showed the marked medicinal effects. For the root part of $R$. nepalensis, for example, antioxidant effects of chloroform and ethyl acetate extracts had been studied using 2,2-Diphenyl-1-picrylhydrazyl(DPPH) and 2,2'azino-bis(3-ethylbenzythiazoline)-6-sulfonic acid (ABTS) free radical assays, where the level of the phenolic compound in ethyl acetate was higher than in the chloroform extract and showed promising activities [24]. In vitro test showed the essential oil from roots of $R$. nepalensis has a comparable antioxidant activity to standards like ascorbic acid and vitamin E [74].

\subsubsection{Antimicrobial activity}

Organic solvents such as benzene, pet ether, chloroform, acetone, ethyl acetate, and methanol extracts of the root part of $R$. nepalensis have been reported showing antimicrobial activity against Gram-positive and Gramnegative microorganisms like Staphylococcus aureus, Streptococcus mutans, Escherichia coli, Pseudomonas aeruginosa, and Candida albicans. Root extracts of the plant by ethyl acetate and benzene showed precise antifungal activity against C. albicans [29]. Chrysophanic acid, one of the chemical constituents obtained from $R$. nepalensis, has been also reported to have antifungal activity [31]. The methanol extract of the root part of $R$. nepalensis has shown inhibitory activity against RNA polymerase of hepatitis $\mathrm{C}$ virus. Its extract has high tannin percentage which also inhibited about $80 \% \mathrm{HCV}$ $\mathrm{RdRp}$ at a concentration of $50 \mu \mathrm{g} / \mathrm{mL}$ [40]. The same report also showed the leaves extract of the plant has antiHIV opportunistic diseases. For example, out of 38 tested $80 \%$ ethanolic leaves extract of the plants from 21 different families, only two plant extracts were reported to show interesting activity index towards HIV-1 in vitro virus test. One of the two plants with good anti-HIV-1 activity indices was $R$. nepalensis [60, 61]. Similarly, methanolic extracts of the plant showed to be an alternative way of medicines to prevent bacterial and fungal infections [53]. The methanol root extract of the plant was investigated on several clinical isolates and standard strains by well diffusion assay which showed moderate inhibitory effect against Escherichia coli (12 mm inhibition zone) for antibacterial activity and Aspergillus niger (11 mm inhibition zone) for antifungal activity due to the presence of anthraquinone, steroid, saponin, reducing sugar, and tannin compounds [75]. It was again reported that $R$. nepalensis methanolic root extract (29 mm inhibition zone) at $1000 \mu \mathrm{g} / \mathrm{mL}$ had shown similar inhibitory activity against Staphylococcus aureus when compared with the positive control Ciprofloxacin $(29 \mathrm{~mm}$ inhabitation zone ) [76]. The leaves and root extracts of $R$. nepalensis were also reported to show significant antimicrobial and antifungal properties [77]. For the leaf aqueous extract of $R$. nepalensis, biocompatible gold nanoparticles were synthesized effectively which showed significant antibacterial activity [78]. 


\subsubsection{Wound healing activity}

The leaves extract of $R$. nepalensis was mixed with Vaseline or butter and applied to the infected body. Antibacterial and antipyretic activities of the plant products further justify $R$. nepalensis application as a traditional medicinal plant to cure wounds $[40,79]$. Secondary metabolites from the plant species were also reported showing wound healing properties [18]. The powder or juice of leaves has revealed the wound healing activity of the plant species [59]. Furthermore, reports have shown methanol extracts of the root part of $R$. nepalensis were revealed promising anti-ulcer activity on pyloric ligation, cold restraint stress, and acetic acid-induced ulcer models which strengthen the claim on the plant as traditional medicinal remedy [80].

\subsubsection{Anti-plasmodial activity}

$R$. nepalensis has been practiced by traditional healers for its anti-plasmodial activity. However, there are very few reports showing anti-plasmodial properties of the plant species. For example, the ethanol fraction of the root of $R$. nepalensis showed improved plasmodium percent suppression $(70.08 \%)$ compared with the water extraction (54.31\%), chloroform extraction (19.61\%), and methanol extraction (10.27 \%) suppression [48].

\subsubsection{Miscellaneous activities}

The crushed root paste of $R$. nepalensis was reported to cure eczema [55]. The plant species has been reported for its application to treat swollen gums, pain, and headaches [81-83]. For instance, methanol extract of the root part of plant species was tested for its purgative activity, and the application of the extract to albino rat at 100 to $400 \mathrm{mg} / \mathrm{Kg}$ as the oral dose showed good purgative activity [44]. It is also used as ethnoveterinary medicine as the crushed leaves have shown positive effects to alleviate stomach disorders in livestock [58]. The juice of the leaves of the plant was used in the ailment of abdominal colic, skin diseases with antiallergic properties [59]. In Ethiopia, the extract of $R$. nepalensis is used for the treatment of diarrhea [84]. For example, chewing fresh root of the plant has shown marked effect in human and livestock for treatment of diarrhea [47]. Meresa et al. [66] reported the impact of boiled extract of fresh leaves to treat diseases like hypertension, amoebic dysentery, and hemorrhoids. When compared with Ruta chalepensis, Clausena anisata, Nocotiana tabacum, and Zingiber officinale, $R$. nepalensis was reported as the most preferred medicinal plant to cure the stomach ache [85]. Chrysophanol and physcion were reported as potential human pancreatic lipase inhibitory phytochemicals. Pancreatic lipase is an enzyme responsible for the reduction of abnormal fat accumulation in the body which is the cause of the risk of overweight and obesity [86].

\section{Conclusions}

In conclusion, this review has outlined the current research trends of $R$. nepalensis regarding its ethnomedicinal importance, phytochemistry, and pharmacological properties. $R$. nepalensis is commonly applied as traditional medicinal plants for the treatment of human diseases. Additionally, its uses are as a food supplement, coloring agent, and potential accumulation of heavy metals (i.e., phytoremediation). Various phytochemical screening on the plant extracts has revealed that it has a wide spectrum of bioactive compounds. The extracts and isolated compounds from $R$. nepalensis showed that they have wide biological applications. The potential bioactive compounds isolated from the plant using different solvent systems are classified as anthraquinones, naphthalenes, stilbenoids, flavonoids, terpenoids, phenols, and their derivatives. Most organic compounds were isolated and reported from the root parts of $R$. nepalesis using common organic solvents like ethyl acetate, pet ether, n-butanol, ethanol, methanol, and methanol/water (80/20) systems. Natural products like chrysophanol, physcion, emodin, endocrocin, torachrysone, orientaloside, aloesin, catechin, and their glycoside derivatives have been reported from the solvent extracts of root, leaves, and aerial parts of the plant species. Compounds like 3-O-methylepicatechin, quercetin-3-O- $\beta$-D-glucoronate, epicatechin-3-O-gallate, orcinol glucoside, and (3,5-dimethoxy-4-hydroxyphenol)1-O- $\beta$-D-(6-O-galloyl) glucose were also the major bioactive compounds reported from the root extracts of the plant species. Pharmacological studies revealed that solvent extracts and secondary metabolites have antimicrobial, antioxidant, anti-inflammatory, anti-plasmodial, and wound healing activities. But, regardless of its potential sources of phytochemical compounds and potential pharmacological activities, the total number of isolated compounds from solvent extracts of plant parts especially from the leaves is too small. Authors of this review article are hoping that the review work has concisely forwarded some important information to scientific communities about the current research trends regarding the phytochemistry and pharmacological applications of $R$. nepalensis plant species. In the future, major research focus should be given toward the phytochemical investigations of the plant parts to isolate more novel bioactive compounds so that they can be used for modern drug synthesis.

\section{Abbreviations \\ BW: Body weight; HCV-RdRb: Hepatitis C virus basolateral cell membrane resistances; HIV-1: Human immunodeficiency virus-1; LD50: Lethal dose, 50\%;} RNA: Ribonucleic acid

Acknowledgements

Not applicable. 


\section{Authors' contributions}

$\mathrm{YH}$ and FB have drafted the review. MG and AB prepared different tables and figures required for the manuscript. RKB provided guidance during development of idea and wrote and revised the manuscript. The authors read and approved the final manuscript

\section{Funding}

None.

\section{Availability of data and materials}

Not applicable.

\section{Declarations}

\section{Ethics approval and consent to participate}

Not applicable.

\section{Consent for publication}

Not applicable.

\section{Competing interests}

The authors declare that they have no competing interests.

\section{Author details}

${ }^{1}$ Chemistry Department, Ambo University, P.O.Box: 19, Ambo, Ethiopia. ${ }^{2}$ Department of Industrial Chemistry, College of Applied Science, Addis Ababa Science and Technology University, P.O.Box: 16417, Addis Ababa Ethiopia. ${ }^{3}$ Chemistry Department, Woldia University, Woldia, Ethiopia. ${ }^{4}$ Department of Environment Science, Graphic Era University, Dehradun, India.

Received: 20 October 2020 Accepted: 2 March 2021

\section{Published online: 18 March 2021}

\section{References}

1. Abduljalil J, Al-rakhami A, Al-haj M, Al-rrimy M, Al-wheabi S (2018) Preliminary phytochemical analysis and antibacterial activity of methanol extracts from Origanum majorana, Rumex nervosus, and Withania somnifera. Int J Pharma Res Health Sci 6:1-7. https://doi.org/10.21276/ijprhs.2018.06.06

2. Duressa T (2016) Vascular plant diversity and ethnobotanical study of medicinal and wild edible plants in Jibat, Gedo and Chilimo Forests, West Shewa Zone of Oromia Region, Ethiopia. PhD Dissertation, Addis Ababa University.

3. Asmamaw D, Achamyeleh H (2018) Assessment of medicinal plants and their conservation status in case of Daligaw Kebele, Gozamen Woreda, East Gojjam Zone. IJBBD 5:1-6. https://doi.org/10.4172/2376-0214.1000170

4. Jain P, Parkhe G (2018) An updated review on pharmacological studies of Rumex nepalensis. J Pharm Innov 7:175-181

5. Fufa $F(2016)$ Phytochemical investigation and in vitro antibacterial evaluation on root extracts of Rumex abyssinicus. Nat Prod Res 4:1-14. https://doi.org/10.4172/2329-6836.1000239

6. Nivedhini V, Chandran R, Parimelazhagan T (2014) Chemical composition and anti-oxidant activity of Cucumis dipsaceus Ehrenb.Ex Spach fruit. Int Food Res 21:1465-1472

7. Kasimala B, Tukue M, Ermias R (2014) Phytochemical screening and antibacterial activity of two common terresterial medicinal plants Ruta chalepensis and Rumex nervosus. Bali Med J 3(3):116-121. https://doi.org/10.1 5562/bmj.v3i3.86

8. Meresa A, Degu S, Tadele A, Geleta B, Moges H (2017) Medicinal plants used for the management of rabies in Ethiopia. Med Chem 7:795-806. https://doi.org/10.4172/2161-0444.1000431

9. Tamiru F, Terfa W, Kebede E, Dabessa G, Roy K (2013) Ethnoknowledge of plants used in veterinary practices in Dabo Hana district, West Ethiopia. J Med Plant Res 7:2960-2971. https://doi.org/10.5897/JMPR2013.5225

10. Hauptvogl M, Kotrla M, Prčík M, Pauková Ž, Kováčik M, Lošák T (2018) Phytoremediation potential of fast-growing energy plants: challenges and perspectives. Pol J Environ Stud 29:1-12. https://doi.org/10.15244/pjoes/10162

11. Khan S, Sajad A, Khan M, Ali Sajjad AH, Naeem A (2015) Phytoremediation of nickel from the effluents of selected ghee industries of Khyber Pakhtunkhwa, Pakistan. JBES 6:174-182
12. Li R, Dong F, Yang G, Zhang W, Zong M, Nie X, Zeng Y (2019) Characterization of arsenic and uranium pollution surrounding a uranium mine in Southwestern China and phyto- remediation potential. Pol J Environ Stud 28:173-185. https://doi.org/10.15244/pjoes/103446

13. Muhammad S, Shah T, Khan S, Saddique U, Gul N, Khan U, Naz A (2013) Wild plant assessment for heavy metal phytoremediation potential along the mafic and ultramafic terrain in Northern Pakistan. BioMed Res Int 8:1-10. https://doi.org/10.1155/2013/194765

14. Shakir U, Gul J, Farzana G, Siraj K, Husna H, Jan S, Syed A (2018) Phytochemistry and anti-bacterial activities of some selected plants of war affected area of Bajaur agency, Pakistan. J Pharmacogn Phytochem 7:415-422

15. Tonny S, Sultana S, Siddika F (2017) Study on medicinal uses of Persicaria and Rumex species of polygonaceae family. J Pharmacogn Phytochem 6: 587-589

16. Bahadur S, Chhetri B, Khatri D (2017) Phytochemical screening, total phenolic and flavonoids content and antioxidant activity of selected Nepalese plants. World J Pharm Pharm Sci 6:951-968. https://doi.org/10.2 0959/wjpps201712-10571

17. Atsushi M, Taro O, Chengwei L, Hideaki O (2018) Cyclopentane-forming di/ sesterterpene synthases: widely distributed enzymes in bacteria, fungi, and plants. Nat Prod Rep 10:1-17. https://doi.org/10.1039/c8np00026c

18. Azher K, Irm J (2018) Extraction, qualitative and quantitative determination of secondary metabolites of Rumex nepalensis roots. J Drug Deliv Ther 8:97100. https://doi.org/10.22270/jddtv8i6-s.2092

19. Johanna D, Virginie $P$, Marion $P$, Eric $L$ (2016) Research advances for the extraction, analysis and uses of anthraquinones. Ind Crops Prod 94:812-833. https://doi.org/10.1016/j.indcrop.2016.09.056

20. Timo D, Stark J, Onesmo B (2013) Ethnopharmacological survey of plants used in the traditional treatment of gastrointestinal pain, inflammation and diarrhea in Africa: future perspectives for integration into modern medicine. Anim 3:158-227. https://doi.org/10.3390/ani3010158

21. Gelana T, Yalemtsehay M (2011) Anti-microbial activity of solvent-extracts of Cucumis ficifolius and Zehneria scabra on some test microorganisms. M.Sc. Thesis, Addis Ababa University.

22. Mhalla D, Bouassida Z, Chawech R, Bouaziz A, Makni S, Jlaiel L, Trigui M (2018) Effects of Rumex tingitanus extracts and identification of a novel bioactive compounds. BioMed Res:1-11. https://doi.org/10.1155/2018/72 95848

23. Alberto J, Diana P, Ríos C, Villanueva L, Murrieta M (2016) Some traditional medicinal plants of North region from Puebla, Mexico: Uses and potential pharmacological activity of Rumex spp. Nat Prod Chem Res 4:1-8. https:// doi.org/10.4172/2329-6836.1000223

24. Vasas A, Orbán-gyapai O, Hohmann J (2015) The Genus Rumex: Review of traditional uses, phytochemistry and pharmacology. J Ethnopharmacol 175: 198-228. https://doi.org/10.1016/j.jep.2015.09.001

25. Sharma R, Jandrotia R, Singh B, Sharma U, Kumar D, Pradesh H (2018) Comprehensive metabolomics study of traditionally important Rumex apecies found in Western Himalayan Region. Nat Prod Commun 13:189-194

26. Ahmad S, Ullah F, Sadiq A, Ayaz M, Imran M, Ali I, Shah M (2016) Chemical composition, antioxidant and anticholinesterase potentials of essential oil of Rumex hastatus D.Don collected from the North West of Pakistan. BMC Complem Altern Med 16:1-11. https://doi.org/10.1186/s12906-016-0998-Z

27. Birhan Y, Kitaw S, Alemayehu Y, Mengesha N (2017) Ethnobotanical study of medicinal plants used to treat human diseases in Enarj Enawga district, East Gojjam Zone, Amhara Region, Ethiopia. J Med Plants Stud 1:1-20

28. Fatima N, Zia M, Rizvi F, Ahmad S, Mirza B, Chaudhary F (2009) Biological activities of Rumex dentatus L: Evaluation of methanol and hexane extracts. Afr J Biotechnol 8:6945-6951

29. Yadav S, Kumar S, Jain P, Pundir K, Jadon S, Sharma A (2011) Antimicrobial activity of different extracts of roots of Rumex nepalensis Spreng. IJNPR 2:65-69

30. Nabiel M, Saleh N (1993) Flavonoids and anthraquinones of some Egyptian Rumex species (Polygonaceae). Biochem Syst 21:301-303. https://doi.org/1 0.1016/0305-1978(93)90049-W

31. Shafiq N, Saleem M, Kousar S, Sahar M, Mahboob S, Jabeen F (2017) Investigation of genus Rumex for their biologically active constituents. Pharm Chem Sci 2:148-165. https://doi.org/10.26479/2017.0206.11

32. Faroog U, Pandith A, Inder M, Saggoo S, Lattoo K (2013) Altitudinal variability in anthra- quinone constituents from novel cytotypes of Rumex nepalensis Spreng: a high value medicinal herb of North Western Himalayas. Ind Crops Prod 50:112-117. https://doi.org/10.1016/j.indcrop.2013.06.044 
33. Hassan N, Wang D, Shuaib M, Zhong Z, Nisar M, Ahmad W, Khan A (2017) Identification and ethnobotanical survey of profitable medicinal plants used as remedy in Sangina Pakistan. Int J Her Med 5:117-123

34. Mishra P, Sharifi-rad M, Shariati A, Mabkhot N, Al-showiman S, Rauf A, Iriti M (2018) Bioactive compounds and health benefits of edible Rumex species. Cell Mol Biol 64:1-8. https://doi.org/10.14715/cmb/2018.64.8.5

35. Esubalew T, Belete A, Lulekal E, Gabriel T, Engidawork E, Asres K (2017) Review of ethnobotanical and ethnopharmacological evidences of some Ethiopian medicinal plants traditionally used for the treatment of cancer. Ethiop J Health Dev 31:1-27

36. Tiwary K, Bihani S, Kumar A, Chakraborty R, Ghosh R (2015) The in vitro cytotoxic activity of ethno-pharmacological important plants of Darjeeling district of West Bengal against different human cancer cell lines. BMC Complement Altern Med 15(1):1-10. https:/doi.org/10.1186/s12906-015-0543-5

37. Tura T, Eshete B, Tucho T (2017) Anti-bacterial efficacy of local plants and their contribution to public health in rural Ethiopia. Antimicrob Resist Infect Control 6:1-7. https://doi.org/10.1186/s13756-017-0236-6

38. Wen W, Zhao H, Ma J, Li Z, Li H, Zhu X (2018) Effects of mutual intercropping on $\mathrm{Pb}$ and $\mathrm{Zn}$ accumulation of accumulator plants Rumex nepalensis, Lolium perenne and Trifolium repens. Chem Ecol 10:1-13. https:// doi.org/10.1080/02757540.2018.1427229

39. Singh N (2012) Traditional knowledge on ethnobotanical uses of plant biodiversity: a detailed study from the Indian Western Himalaya. Biodiv Res Conserv 28:63-77. https://doi.org/10.2478/v10119-012-0028-z

40. Kumar V, Ganeshkhind C, Shriram V (2018) A critical review on Nepal Dock (Rumex nepalensis): a tropical herb with immense medicinal importance. Asian Pac J Trop Med 2:405-414. https://doi.org/10.4103/1995-7645.237184

41. Wangchuk K (2015) Himalayan dock (Rumex nepalensis): the flip side of obnoxious weed. J Anim Sci Technol 57:1-5. https://doi.org/10.1186/s40781015-0067-z

42. Shrestha L, Timilsina N (2017) Anti-oxidant and anti-microbial activity and GCMS analysis of extract of Rumex nepalensis Spreng. J Pharma Innov 6:155-158

43. Kaur D, Singhal K (2016) Ethnobotanical uses, chromosome counts and male meiotic studies in selected medicinal herbs from Kinnaur district of Himachal Pradesh, India. World J Pharm Pharm Sci 5:912-935. https://doi. org/10.20959/wjpps20165-6664

44. Ghosh L, Gayen R, Murugesan T, Sinha S, Pal M, Saha P (2003) Evaluation of purgative activity of roots of Rumex nepalensis. Fitoterapia 74:372-374. https://doi.org/10.1016/S0367-326X(03)00063-7

45. Awais S, Ahmad I, Saeed S, Hassan U, Yousaf H, Butt J (2017) Phytochemical and biological evaluation of $R$. hastatus and $R$. himalyica from Galiyat Pakistan. J Pharm Res Int 19:1-9. https://doi.org/10.9734/JPRI/2017/37143

46. Enyew A, Asfaw Z, Kelbessa E, Nagappan R (2014) Ethnobotanical study of traditional medicinal plants in and around Fiche District, Central Ethiopia. Curr Res J Biol Sci 6:154-167

47. Habtamu A (2017) Evaluation of the anti-plasmodial and anti-microbial properties of the medicinal plants Rumex nepalensis Spreng. and Centella asiatica L. M.Sc. Thesis, Addis Ababa University.

48. Al-naqeb G, Deen A (2017) The effect of Rumex nervosus Vahl leaves on high fat diet-induced hyperglycemia and hyperlipidemia in albino rats. Int J Chem 1:80-83

49. Chekole $\mathrm{G}$ (2017) Ethnobotanical study of medicinal plants used against human ailments in Gubalafto district, Northern Ethiopia. J Ethnobiol Ethnomed 13:1-29

50. Lulekal E, Rondevaldova J, Bernaskova E, Cepkova J, Asfaw Z, Kelbessa E, Kokoska L (2013) Anti-microbial activity of traditional medicinal plants from Ankober district, North Shewa Zone, Amhara Region, Ethiopia. Pharm Biol 8:1-7

51. Liang H, Dai H, Fu H, Dong X, Humphrey A, Zhang L, Cheng Y (2010) Bioactive compounds from Rumex plants. Phytochem Lett 3:181-184. https://doi.org/10.1016/j.phytol.2010.05.005

52. Gaire P, Subedi L (2011) Medicinal plant diversity and their pharmacological aspects of Nepal Himalayas. Pharmacogn J 3:1-12. https://doi.org/10.5530/ pj.2011.25.2

53. Kumar S, Joseph L, George M, Kaur L, Bharti V (2011) Skeletal muscle relaxant activity of methanolic extract of Rumex nepalensis in albino rats. J Chem Pharm 3:725-728

54. Rawat S, Jalal S (2011) Sustainable utilization of medicinal plants by loca community of Uttarkashi district of Garhwal, Himalaya, India. Eur J Med Plants 1:18-25

55. Ramasubramania R, Hussainaiah D, Amarnath K (2012) Skin diseases and folklore remedies: An ethnobotanical approach. J Pharm Res 5:987-989
56. Abebe E (2011) Ethnobotanical study on medicinal plants used by local communities in Debark Woreda, North Gonder Zone, Amhara Regional State, Ethiopia. M.Sc. Thesis, Addis Ababa University.

57. Etana B (2010) Dryland biodiversity stream ethnobotanical study of traditional medicinal plants of Goma Wereda, Jima Zone of Oromia Region, Ethiopia. M.Sc. Thesis, Addis Ababa University.

58. Bussmann W, Swartzinsky P, Worede A, Evangelista P (2011) Plant use in Odo-Bulu and Demaro, Bale, Ethiopia. J Ethnobiol Ethnomed 7:1-21

59. Dwivedi T, Kanta C, Singh R, Prakash I (2019) A list of some important medicinal plants with their medicinal uses from Himalayan State. J Med Plants Stud 7:106-116

60. Maroyi A (2014) Alternative medicines for HIV/AIDS in resource-poor settings: insight from traditional medicines use in Sub-Saharan Africa. Trop J Pharm Res 13:1527-1536. https://doi.org/10.4314/tjpr.v13i9.21

61. Cosa H, Bruyne S, Sindambiwe M, Witvrouw E, Vanden B, Pieters V (2002) Anti-viral activity of Rwandan medicinal plants against human immunodeficiency virus type-1(HIV-1). Phytomedicine 9:62-68. https://doi. org/10.1078/0944-7113-00083

62. Amjad S, Arshad M, Qureshi R (2015) Ethnobotanical inventory and folk uses of indigenous plants from Pir Nasoora National Park, Azad Jammu and Kashmir. Asian Pac J Trop Biomed 5(3):234-241. https://doi.org/10.1016/ S222116911530011-3

63. Awan I, Awan A, Aziz F, Khan N (2013) Ethnobotanical importance of some highly medicinal plants of district Muzaffarabad, Pakistan with special reference to the species of the genus Viburnum. J Pharm Biol Sci 6:53-66

64. Murtem G, Chaudhry P (2016) An ethno-botanical study of medicinal plants used by the tribes in upper Subansiri district of Arunachal Pradesh, India. Am J Ethnomed 3:35-49

65. Srivastav M, Kumar A, Hussain T (2015) Diversity of angiospermic plants in Dhanaulti Region, Uttarakhand: an emerging tourist destination in Western Himalaya. Biodivers Data J 11:1-10. https://doi.org/10.15560/11.4.1702

66. Meresa A (2017) An ethno-botanical review on medicinal plants used for the management of hypertension. J Clin Exp Pharmacol 7:1-16. https://doi. org/10.4172/2161-1459.1000228

67. Mei R, Liang H, Wang J, Zeng L, Lu Q, Cheng Y (2009) New secoanthraquinone glucosides from Rumex nepalensis. Planta Med 75:1162-1164. https://doi.org/10.1055/s-0029-1185467

68. Raju G, Amit S, Sanjay J (2010) Simultaneous determination of naphthalene and anthra- quinone derivatives in Rumex nepalensis Spreng. roots by HPLC: comparison of different extraction methods and validation. Phytochem Anal 76:153-157. https://doi.org/10.1002/pca.1261

69. Nagarajan A, Rajkumar G, Sellamuthu M, Venkataramegowda S, Anita M (2012) Evaluation of Basella rubra L., Rumex nepalensis Spreng., and Commelina. Int J Pharm Pharm Sci 4:1-8

70. Grover J, Kumar V, Singh V, Bairwa K, Sobhia E, Jachak M (2014) Synthesis, biological evaluation, molecular docking and theoretical evaluation of ADMET properties of nepodin and chrysophanol derivatives as potential cyclooxygenase(COX-1, COX-2) inhibitors. Eur J Med Chem 80:47-56. https://doi.org/10.1016/j.ejmech.2014.04.033

71. Wagas M, Afridi S, Ahmad N, Sohail A, Hayat A, Ramzan R, Niaz M (2016) Anti-microbial activity of Rumex Nepalensis and Urtica Diocia. Int J Sci Res 5: 1563-1566

72. Choi H, Lee B, Lee O (2013) Anti-oxidant activity and anti-adipogenic effects of wild herbs mainly cultivated in Korea. Molecules 18:12937-12950. https:// doi.org/10.3390/molecules181012937

73. Devkota R, Paudel R, Baral A, Bahadur S, Chhetri B (2015) Investigation of anti-oxidant and anti-inflammatory activity of roots of Rumex nepalensis. World J Pharm Pharm Sci 4:582-594

74. Sanjay K, Pramod S (2020) Phytochemical investigation and anti-oxidant characterization of essential oil from roots of Rumex nepalensis Spreng. high altitude of North India. Mater Today 26:3442-3448. https://doi.org/10.1016/j. matpr.2019.12.227

75. Surjeet K, Lincy J, Mathew G, Vivek B (2011) Anti-microbial activity of methanolic extract of Rumex nepalensis leaves. Int J Pharm Pharm 3:240-242

76. Sneh Y, Sanjeev K, Pranay J, Ram KP, Sudha J, Abha S, Kishan C (2011) Antimicrobial activity of different extracts of roots of Rumex nepalensis Spreng. IJNPR 2:65-69

77. Nikodimos E, Adane T, Tegene N (2020) Evaluation of abortifacient effect of Rumex nepalensis Spreng. among pregnant Swiss albino rats: Laboratorybased study. J Exp Pharmacol 12:255-265 
78. Muhammad I, Ghulam M (2020) Green synthesis of gold nanoparticles using Rumex nepalensis leaf extract and evaluation of antibacterial efficacy. Int J Biol Biotech 17:227-234

79. Shaheen B, Naser A, Muhammad A, Akash T (2014) Ethnomedicines of highly utilized plants in the temperate Himalayan region. Tradit Complement Altern Med 11:132-142. https://doi.org/10.4314/ajtcam.v11i3.20

80. Sisay Z, Jembere A (2020) Evaluation of the anti-ulcer activity of the hydromethanolic crude extract and solvent fractions of the root of Rumex nepalensis in rats. J Exp Pharmacol 12:325-337

81. Dastagir G, Hameed I (2009) Nutritional analyses of Rumex hastatus D. Don, Rumex dentatus Linn, and Rumex nepalensis Spreng. Afr J Biotechnol 8:4131-4133

82. Monika R, Meenakshi R, Deepika C (2017) Commonly used medicinal plants in Tehsil Bangana, Una district, Himachal Pradesh. J Ayu Her Med 3:102-107

83. Ginson G, Pracheta S, Atish T (2020) Optimization of an extraction conditions for Rumex nepalensis anthraquinones and its correlation with pancreatic lipase inhibitory activity. J Food Compost Anal 92:1-7. https:// doi.org/10.1016/j.jfca.2020.103575

84. Mungole A, Chaturvedi A (2011) Determination of anti-bacterial activity of two medicinally important Indian Taxa. Der Pharma Chemica 3:83-89

85. Woldeab B, Regassa R, Alemu T, Megersa M (2018) Medicinal plants used for treatment of diarrhoeal related diseases in Ethiopia. J Pharm:1-20. https:// doi.org/10.1155/2018/4630371

86. Temam T, Dill A (2016) Ethnobotanical study of medicinal plants of MirabBadwacho district, Ethiopia. J BioSci Biotechnol 5:151-158

\section{Publisher's Note}

Springer Nature remains neutral with regard to jurisdictional claims in published maps and institutional affiliations.

\section{Submit your manuscript to a SpringerOpen ${ }^{\circ}$ journal and benefit from:}

- Convenient online submission

- Rigorous peer review

- Open access: articles freely available online

- High visibility within the field

- Retaining the copyright to your article

Submit your next manuscript at $\boldsymbol{\nabla}$ springeropen.com 